\title{
DAMPAK PEMBANGUNAN EKONOMI, PENGELUARAN RUMAH TANGGA, DAN KETERBUKAAN PERDAGANGAN TERHADAP KONSUMSI ENERGI FINAL DI INDONESIA
}

\author{
Bambang Priyo Cahyono \\ Fakultas Ekonomi, Universitas Islam Attahiriyah, Jakarta \\ Email: dli.bambang@gmail.com \\ Yusro Hakimah \\ Fakultas Teknik, Universitas Tridinanti, Palembang \\ Email: yusrohakimah@yahoo.co.id

\section{DOI. 10.35908/jeg.v4i2.751}

Received: March 14, 2019, Revised: April 15, 2019, Accepted: June 09, 2019

\begin{abstract}
This study investigates the impact of economic growth on three main development sectors, household final consumption expenditure, and trade openness towards the growth of final energy consumption in Indonesia using annual data for the period 1972-2016. We applied autoregressive distributed lag (ARDL) procedures which consist of stationarity test, cointegration test, as well as estimation the short-term and long-term relationships. The cointegration test revealed existence cointegration relationship among the variables in the model. In the short-term and long-term model, our results indicated that the growth of value-added in agriculture sector and industry sector, household final consumption expenditures, and trade openness in the short-term and long-term have a significant effect toward final energy consumption in Indonesia, while the growth of value-added in the service sector only given a short-term effect toward final energy consumption in Indonesia. Based on these results, it can be concluded that sustainable economic development in Indonesia needs to be accompanied by the development of new and renewable energy in order to fulfil domestic energy supply which is predicted to continue to increase rapidly in the future.

Keyword : final energi consumption, economic development, household final consumption expenditure, trade openness, autoregressive distributed lag modeling

JEL Classification : D1, E21, F14, O13, Q43.
\end{abstract}

\begin{abstract}
ABSTRAK
Studi ini menyelidiki dampak pertumbuhan ekonomi pada tiga sektor pembangunan utama, pengeluaran konsumsi akhir rumah tangga, dan keterbukaan perdagangan terhadap pertumbuhan konsumsi energi final di Indonesia menggunakan data tahunan untuk periode 1972-2016. Kami menerapkan prosedur Autoregressive Distributed Lag (ARDL) yang terdiri dari uji stasioneritas, uji kointegrasi, serta estimasi hubungan jangka pendek dan jangka panjang. Uji kointegrasi mengungkapkan adanya hubungan kointegrasi antara variabel dalam model. Dalam model jangka pendek dan jangka panjang, hasil kami menunjukkan bahwa pertumbuhan nilai tambah di sektor pertanian dan sektor industri, pengeluaran konsumsi akhir rumah tangga, dan keterbukaan perdagangan dalam jangka pendek dan jangka panjang memiliki pengaruh yang signifikan terhadap Konsumsi energi final di Indonesia, sementara pertumbuhan nilai tambah di sektor jasa hanya memberikan efek jangka pendek terhadap konsumsi energi final di Indonesia. Berdasarkan hasil ini, dapat disimpulkan bahwa pembangunan ekonomi berkelanjutan di Indonesia perlu dibarengi dengan pengembangan energi baru dan terbarukan untuk memenuhi pasokan energi domestik yang diprediksi akan terus meningkat dengan cepat di masa mendatang.

Kata kunci: konsumsi energi final, pembangunan ekonomi, pengeluaran konsumsi rumah tangga, keterbukaan perdagangan, autoregressive distributed lag modelling.

Klasifikasi JEL : D1, E21, F14, O13, Q43.
\end{abstract}




\section{Pendahuluan}

Saat ini, energi telah menjadi salah satu kebutuhan penting bagi kehidupan manusia dan hampir semua aktifitas masyarakat membutuhkan energi. Pemanfaatan energi telah bagian dalam kompleksitas sistem sosial ekonomi karena hampir semua aktivitas manusia akan terkait erat dengan kegiatan produksi, transformasi, konversi, dan konsumsi energy (Javid \& Sharif, 2016). Sebagai komponen kunci yang mendorong proses pembangunan berkelanjutan di suatu negara, energi telah dianggap sebagai instrumen penting yang merangsang pertumbuhan ekonomi dan mempercepat kegiatan pembangunan di semua sektor produktif seperti kesehatan, pendidikan, pertanian, perdagangan, transportasi, industri, dan lainnya (Aramcharoen \& Mativenga, 2014). Pasokan energi yang memadai sangat diperlukan untuk meningkatkan standar kehidupan masyarakat, kualitas dan kuantitas sumber daya manusia, kegiatan komersial dan bisnis, kelestarian lingkungan, dan efisiensi kebijakan pemerintah di suatu negara (Alam et al, 2016; Saez-Martinez et al, 2015).

Indonesia adalah negara terpadat ke-empat di dunia dengan jumlah populasi lebih dari 264 juta orang pada tahun 2017 (World Bank, 2018). Lebih dari setengah populasi penduduk di Indonesia tinggal di perkotaan dengan laju pertumbuhan populasi perkotaan sekitar 2,9\% pertahun selama periode 2000-2017. Dari sudut pandang permintaan, populasi perkotaan cenderung mengkonsumsi lebih banyak kebutuhan barang dan jasa serta produk energi final dibandingkan wilayah pedesaan (Azamet al, 2015a). Sebagai salah satu negara dengan laju pertumbuhan ekonomi terbesar di asia tenggara, tingkat pertumbuhan PDB rill Indonesia meningkat rata-rata sekitar $5,3 \%$ pertahun selama periode 2000-2017. Semakin meningkatnya urbanisasi di Indonesia secara tidak langsung dianggap mendorong laju pertumbuhan pengeluaran konsumsi akhir rumah tangga dan semakin meningkatnya keterbukaan perdagangan (ekspor dan impor).

Tabel 1. Pertumbuhan PDB riil, Pengeluaran Konsumsi Akhir Rumah Tangga, dan Keterbukaan Perdagangan di Indonesia, 2000-2017.

\begin{tabular}{|c|c|c|c|c|c|c|}
\hline Indikator & 2000 & 2004 & 2008 & 2012 & 2016 & 2017 \\
\hline Total Populasi $^{\mathrm{a}}$ & 211,54 & 223,61 & 236,16 & 248,88 & 261,12 & 263,99 \\
\hline a) perkotaan $^{a}$ & 88,85 & 100,96 & 114,15 & 127,62 & 140,97 & 144,29 \\
\hline b) Pedesaan ${ }^{a}$ & 122,69 & 122,65 & 122,01 & 121,27 & 120,14 & 119,70 \\
\hline PDB riil $^{\mathrm{b}}$ & 453.41 & 540.44 & 679.40 & 850.02 & 1037.86 & 1090.46 \\
\hline a) Pertanian ${ }^{b}$ & 74.83 & 85.30 & 98.22 & 114.34 & 133.19 & 138.27 \\
\hline b) Industri ${ }^{\text {b }}$ & 216.47 & 250.05 & 297.19 & 361.73 & 420.68 & 437.87 \\
\hline c) Pelayanan ${ }^{b}$ & 155.28 & 195.18 & 267.64 & 355.60 & 446.89 & 472.25 \\
\hline $\begin{array}{l}\text { Pengeluaran Konsumsi } \\
\text { Rumah Tangga }^{\text {b }}\end{array}$ & 278.00 & 325.80 & 386.50 & 470.57 & 575.48 & 604.17 \\
\hline
\end{tabular}




$\begin{array}{lllllll}\text { Perdagangan }^{\mathrm{b}} & 323.90 & 322.97 & 397.87 & 421.47 & 388.56 & 431.13\end{array}$

Sumber : World Development Indicator (World Bank, 2018).

Keterangan : a jumlah penduduk dalam juta jiwa

b nilai dalam jutaan USD, harga konstan 2010.

Pertumbuhan ekonomi Indonesia juga tentunya juga tidak lepas dari peran dan kinerja dari tiga sektor utama pembangunan, yaitu sektor pertanian, sektor industri dan sektor pelayanan (Nugraha \& Osman, 2019). Berdasarkan laporan tahunan World Development Indicator (World Bank, 2018), penyumbang nilai tambah terbesar pada PDB rill Indonesia pada tahun 2017 adalah sektor pelayanan dan sektor industri, sementara sisanya disumbangkan oleh sektor pertanian. Kondisi ini menunjukan bahwa sektor pelayanan dan sektor industri memiliki peran besar dalam pembangunan ekonomi di Indonesia dan oleh sebab itu untuk meningkatkan kinerja ekonomi maka dalam satu dekade terakhir pemerintah Indonesia terus memperbaiki iklim usaha dan investasi di dalam negeri agar dapat memaksimalkan pendapatan dari kedua sektor pembangunan utama ini (Bank Indonesia, 2018).

Pembangunan ekonomi berkelanjutan secara tidak langsung memiliki andil besar dalam mendorong semakin meningkatnya jumlah kebutuhan konsumsi energi akhir di Indonesia. Menurut laporan tahunan dari International Energi Agency (2018), total Tabel 2. Pertumbuhan konsumsi energi akhir di Indonesia berdasarkan kelompok pengguna energi final, 2000-2016 (dalam kilo ton setara minyak)

\begin{tabular}{lccccc}
\hline \multicolumn{1}{c}{ Kategori } & $\mathbf{2 0 0 0}$ & $\mathbf{2 0 0 4}$ & $\mathbf{2 0 0 8}$ & $\mathbf{2 0 1 2}$ & $\mathbf{2 0 1 6}$ \\
\hline Industri & 30.129 & 35.575 & 41.904 & 40.318 & 38.830 \\
Transportasi & 20.848 & 23.703 & 24.605 & 44.365 & 47.249 \\
Perumahan & 52.764 & 55.395 & 55.424 & 59.569 & 63.161
\end{tabular}




\begin{tabular}{lrrrrc} 
Pelayanan komersial dan publik & 2.887 & 3.541 & 3.940 & 5.195 & 5.803 \\
Pertanian/Kehutanan & 2.849 & 3.209 & 2.734 & 2.766 & 2.162 \\
Pengguna bukan bahan bakar & 9807 & 9592 & 9129 & 10284 & 7351 \\
Pengguna tidak spesifik & 950 & 852 & 471 & 277 & 172 \\
\hline Total & 120.234 & 131.867 & 138207 & 162.773 & 164.728
\end{tabular}

Sumber : International Energi Agency (2018).

Sektor energi Indonesia sangat bergantung pada beberapa jenis produk energi yang dihasilkan dari fosil. Semua ini menunjukkan peran penting energi fosil dan kontribusi paling sedikit dari energi baru dan terbarukan dalam sumber daya energi tradisional Indonesia. Sejak tahun 2004, Indonesia telah menjadi negara importir komoditas minyak bumi meskipun masih merupakan salah satu anggota organisasi negara-negara pengekspor minyak (OPEC). Indonesia sempat memutuskan untuk menangguhkan keanggotaannya di OPEC pada tahun 2008, namun kembali menjadi anggota organisasi tersebut pada pemerintahan Joko Widodo pada tahun 2014. Resosudarmo et al (2012) berpendapat bahwa peningkatan konsumsi energi dalam dua dekade terakhir sebagian besar disebabkan oleh pertumbuhan sektor industri. Menurut Dutu (2016), dalam rangka menghadapi tantangan isu keamanan energi, Indonesia diharapkan lebih meningkatkan efisiensi energy dan terus mendorong pengembangan energi baru dan terbarukan yang ramah lingkungan.

Menurut Bhattacharyya (2011), permintaan energi dapat muncul karena berbagai alasan. Rumah tangga mengkonsumsi energi untuk memenuhi kebutuhan tertentu dan mereka melakukannya dengan mengalokasikan pendapatan mereka di antara berbagai kebutuhan yang bersaing untuk memperoleh tingkat kepuasan terbesar dari total pengeluaran. Pengguna industri dan komersial mengkonsumsi energi sebagai input produksi dan sarana penunjang aktivitas yang tujuannya adalah untuk meminimalkan total biaya produksi. Hal ini menunjukan bahwa motivasi penggunaan energi pada rumah tangga dan pengguna energi yang produktif tidak sama. Oleh sebab itu perlu dikaji bagaimana peran pertumbuhan ekonomi pada kategori-kategori ini terhadap laju peningkatan konsumsi energi pada suatu negara. Pengetahuan mengenai hubungan kinerja pembangunan ekonomi terhadap konsumsi energi dianggap sebuah kebutuhan dalam upaya menentukan kebijakan dan strategi yang tepat dalam menghadapi tantangan bidang ekonomi dan energi di suatu wilayah.

Sumber daya energi memiliki peran penting dalam keberlangsungan proses pembangunan, aktifitas masyarakat, dan kegiatan perdagangan di Indonesia. Oleh sebab itu penelitian ini bertujuan menyelidiki seberapa besar pengaruh pertumbuhan ekonomi, peningkatan pengeluaran konsumsi akhir rumah tangga dan keterbukaan perdagangan terhadap peningkatan konsumsi energi di Indonesia. Hasil temuan penelitian ini diharapkan dapat memberikan kontribusi informasi dan referensi bagi para pemangku kebijakan di Indonesia dalam rangka 
menentukan strategi dan kebijakan yang tepat dalam menghadapi tantangan di bidang energi dan ekonomi pada masa depan. Selain itu, penelitian ini juga diharapkan dapat memberikan kontribusi pada literature ilmiah yang menyelidiki hubungan antara pertumbuhan ekonomi dan konsumsi energi di suatu negara. Selanjutnya makalah ini disusun sebagai berikut: Bagian kedua mendiskusikan kajian studi literatur sebelumnya, bagian ketiga menjelaskan data dan prosedur metode analisis, bagian ke-empat menyajikan hasil analisis serta diskusi singkat berkaitan temuan, sedangkan bagian terakhir menafsirkan kesimpulan dan implikasi kebijakan berkaitan penelitian ini.

\section{Tinjauan Pustaka}

Selama tiga decade, isu berkaitan peran pertumbuhan ekonomi, belanja rumah tangga dan keterbukaan perdagangan terhadap pertumbuhan konsumsi energi pada suatu negara maupun sekelompok negara telah banyak diselidiki oleh banyak akademisi dan peneliti di seluruh dunia. Beberapa penelitian tersebut sebagian menghasilkan temuan dan bukti empiris yang berbeda yang kemungkinan disebabkan oleh perbedaan metode analisis, periode waktu dan indicator yang digunakan dalam penelitian (Apergis \& Tang, 2013; Ozturk, 2010). Meskipun begitu, temuan dan rekomendasi yang dihasilkan dari temuan tersebut masih dianggap relevan sebagai bahan referensi dan informasi dalam penentuan kebijakan di bidang di energi pada masing-masing wilayah yang diteliti. Pada sisi lain, perbedaan temuan untuk kasus pada negara yang sama juga secara tidak langsung mendorong semakin berkembangnya metode pendekatan yang diterapkan pada penelitian lebih lanjut dalam kasus yang sama.

Untuk kasus di Indonesia, sebagian peneliti menemukan bukti bahwa pertumbuhan PDB riil memiliki dampak signifikan terhadap peningkatan konsumsi energidi Indonesia (Azam et al, 2015b; Chiou-Wei et al, 2008; Hwang \& Yoo, 2014; Mahadevan \& Asafu-Adjaye, 2007; Shahbazet al, 2013a). Hasil temuan ini menggambarkan bahwa peningkatan konsumsi energi dipengaruhi oleh laju pertumbuhan ekonomi dan oleh sebab itu kebijakan konservasi dan mitigasi energi dianggap akan sulit diterapkan karena dikhawatirkan akan mempengaruhi keberlanjutan pertumbuhan ekonomi di Indonesia. Sebaliknya, ada beberapa peneliti yang juga menemukan bukti bahwa laju pertumbuhan PDB rill tidak memiliki hubungan signifikan terhadap peningkatan konsumsi energi di Indonesia (Azamet al, 2015a; Saboori dan Sulaiman, 2013; Yildirim dkk, 2014).vPada hasil temuan ini, sebagian peneliti menyimpulkan bahwa penerapan kebijakan konservasi dan mitigasi energi tidak akan menghambat keberlanjutan kinerja pertumbuhan ekonomi di Indonesia.

Pembangunan ekonomi di suatu negara dipengaruhi oleh kinerja pertumbuhan nilai tambah yang disumbangkan oleh sektorsektor pembangunan terhadap PDB rill serta semakin meningkatnya daya beli masyarakat yang dicerminkan dari pertumbuhan pengeluaran konsumsi akhir rumah tangga. Nugraha \& Osman(2018) dengan menggunakan metode Autoregressive Distributed Lags dan data tahunan selama periode 1971-2014 menemukan bukti bahwa pertumbuhan nilai tambah tiga sektor utama 
pembangunan dan pengeluaran rumah tangga memiliki pengaruh jangka pendek dan jangka panjang terhadap konsumsi energi di Indonesia. Selanjutnya, Nugraha \& Osman(2019) dengan menggunakan data tahunan selama 1975-2014 dan uji Granger-causality berbasis model koreksi kesalahan vector (VECM) menemukan bahwa pertumbuhan nilai tambah sektor pertanian dan sektor pelayanan hanya memiliki pengaruh jangka pendek terhadap pertumbuhan konsumsi energi. Meskipun terdapat perbedaan yang mungkin diakibatkan perbedaan metode dan periode waktu yang digunakan dalam analisis, namun kedua penelitian itu setidaknya menggambarkan bahwa pertumbuhan nilai tambah sektor-sektor pembangunan utama memiliki dampak terhadap pertumbuhan konsumsi energi di Indonesia.

Hubungan konsumsi energi dan pertumbuhan ekonomi pada beberapa sektor pembangunan pada suatu negara juga sudah diselidiki oleh Zachariadis (2007) dan Nugraha \& Osman (2017). Zachariadis (2007) menyelidiki hubungan konsumsi energi dan pertumbuhan ekonomi pada sektor industri, sektor pelayanan, sektor transportasi, dan residential untuk negara-negara G7 dan menyimpulkan bahwa pertumbuhan ekonomi memiliki kontribusi terhadap pertumbuhan konsumsi energi pada sektorsektor pembangunan tertentu di suatu negara. Selanjutnya, Nugraha \& Osman (2017) menyelidiki hubungan antara konsumsi energi dan pertumbuhan ekonomi pada tiga sektor utama pembangunan di Indonesia dan menemukan bukti bahwa pertumbuhan nilai tambah pada masing-masing sektor pembangunan memiliki pengaruh signifikan terhadap pertumbuhan konsumsi energi mereka, khususnya dalam jangka panjang. Berkaitan temuan ini maka dapat disimpulkan bahwa pertumbuhan ekonomi pada masing-masing sektor pembangunan atau kelompok pengguna energi memiliki kontribusi berbeda terhadap laju pertumbuhan konsumsi energi di suatu negara.

Sektor perumahan atau rumah tangga adalah salah satu pengguna energi terbesar dihampir seluruh negara di dunia. Menurut Aydin \& Brounen (2019), penggunaan energi pada rumah tangga adalah kombinasi dari penggunaan tenaga listrik dan bahan bakar (untuk keperluan memasak). Perilaku konsumsi energi oleh rumah tangga dipengaruhi oleh faktor personal (gaya hidup), lingkungan dan budaya atau kebiasaan yang berlaku (Van Raaij \& Verhallen, 1983; Verhallen \& Van Raaij, 1981). Komoditas energi telah menjadi salah satu kebutuhan rumah tangga yang sangat terkait dengan tingkat pendapatan dan pengeluaran rumah tangga. Oleh sebab itu pengeluaran konsumsi final rumah tangga dianggap sebagai salah satu indikator yang merepresentasikan peningkatan kesejahteraan rumah tangga dan berbanding lurus dengan jumlah komoditas energi yang dikonsumsi pengguna energi perumahan (Zachariadis, 2007; Bhattacharyya, 2011; Nugraha \& Osman, 2019).

Pertumbuhan konsumsi energi juga dianggap memiliki keterkaitan dengan semakin berkembangnya aktivitas keterbukaan perdagangan. Berkaitan dengan issue ini, beberapa peneliti telah menemukan bukti pengaruh keterbukaan perdagangan terhadap konsumsi energipada suatu negara maupun panel dari beberapa negara. Shahbaz et al (2015) 
dan Sulaiman et al (2013) menemukan bukti bahwa peningkatan aktivitas keterbukaan perdagangan memiliki efek signifikan terhadap pertumbuhan konsumsi energi di Malaysia. Penelitian Shahbazet al (2013b) juga mengungkapkan bahwa keterbukaan perdagangan sangat terkait dengan konsumsi energi di China. Tiba \& Frikha (2018) menggunakan panel data 24 negara berpendapatan menengah dan tinggi menemukan bukti bahwa keterbukaan perdagangan memiliki efek positif dan mendorong peningkatan konsumsi energi. Al-mulali (2012) mengunakan panel data dari 12 negara timur tengah menemukan bukti bahwa keterbukaan perdagangan dan konsumsi energi memiliki hubungan dua arah yang signifikan dan saling mempengaruhi.

\section{Data and Metodologi}

Penelitian ini menggunakan data tahunan untuk Indonesia selama periode 19722016. Data tahunan konsumsi akhir energi Indonesia (dalam kilo ton setara minyak) yang diperoleh International Energi Agency (IEA, 2018), sementara data tahunan nilai tambah tiga sektor pembangunan (dalam harga konstan 2010 USD), pengeluaran akhir rumah tangga (dalam harga konstan 2010 USD), dan keterbukaan perdagangan (persentase nilai tambah perdagangan dalam PDB Indonesia) diperoleh dari laporan tahunan World Development Indicator (World Bank, 2019). Seluruh seri data yang dikumpulkan untuk penelitian ini kemudian ditransformasi ke dalam bentuk logaritma natural dan dianalisis menggunakan program statistik Eviews versi 9.5. Selanjutnya, model persamaan yang digunakan untuk menyelidiki peran pertumbuhan ekonomi, pengeluaran akhir rumah tangga dan keterbukaan perdagangan terhadap konsumsi akhir energi di Indonesia adalah sebagai berikut :

$L F E=f(L V A, L V I, L V S, L H E, L T R)$

Dimana, L adalah symbol bentuk logaritma natural, FE adalah konsumsi akhir energi, VA adalah nilai tambah sektor pertanian, VI adalah nilai tambah sektor industri, VS adalah nilai tambah sektor pelayanan, HE adalah pengeluaran akhir rumah tangga, dan TR adalah keterbukaan perdagangan.

Prosedur analisis dalam penelitian ini terdiri dari tiga langkah. pada langkah pertama kita memeriksa stasionaritas data seri dengan menggunakan uji Augmented Dickey Fuller (Dickey \& Fuller, 1979) dan Phillips-Perron (Perron \& Phillips, 1988). Pilihan tes PP untuk melengkapi tes ADF dimotivasi oleh argumen bahwa tes ADF memiliki daya rendah untuk menolak unit root sedangkan tes PP mengoreksi korelasi serial dalam pengujian unit root (Wahid, Azlina, \& Mustapa, 2013). Pada prosedur ini masing-masing data seri diuji dengan 2 (dua) spesifikasi, yaitu "hanya dengan intercept" dan "dengan intersep dan tren". Jika data seri ditemukan tidak stasioner pada bentuk $\mathrm{I}(0)$ maka data seri tersebut ditransformasi ke bentuk perbedaan pertama I(1) dan kemudian diuji kembali dengan prosedur yang sama. Umumnya, data seri akan stationer pada bentuk $\mathrm{I}(0)$ dan/atau I(1), Oleh sebab itu diharapkan seluruh data seri yang digunakan dalam analisis dapat stationer pada bentuk $\mathrm{I}(0)$ dan/atau I(1).

Pada langkah kedua, kami memeriksa kointegrasi dengan uji terikat Autoregressive Distributed Lags (ARDL) yang diperkenalkan oleh Pesaran \& Shin 
(1998) and Pesaran et al(2001). Uji terikat ARDL memiliki kelebihan dibandingkan metode pendekatan kointegrasi lainnya. Pertama, teknik ini relatif lebih baik ketika menggunakan jumlah sampel kecil atau terbatas yang terdiri dari 30-80 pengamatan (Mah, 2000).Kedua, kerangka kerja ARDL ini hanya mensyaratkan tak satupun variabel terintegrasi pada I(2). Dengan kata lain, teknik ini dapat diterapkan dengan variabel-variabel yang stationer pada I(0), I(1), atau campuran keduanya. Ketiga, pendekatan ini dapat merepresentasikan hubungan jangka pendek dan jangka panjang dengan hasil perkiraan yang tidak bias (Afzal et al, 2013). Berdasarkan persamaan 1, bentuk persamaan untuk uji terikat ARDL pada penelitian ini dapat ditulis sebagai berikut :

$$
\begin{aligned}
& \Delta L F E_{t}=\beta_{1}+\sum_{i=1}^{k} \beta_{1} L F E_{t-i}+ \\
& \sum_{i=0}^{l} \beta_{2} \Delta L V A_{t-i}+ \\
& \sum_{i=0}^{m} \beta_{3} \Delta L V I_{t-i}+ \\
& \sum_{i=0}^{n} \beta_{4} \Delta L V S_{t-i}+ \\
& \sum_{i=0}^{o} \beta_{5} \Delta L H E_{t-i}+ \\
& \sum_{i=0}^{p} \beta_{6} \Delta L T R_{t-i}+\delta_{1} L F E_{t-i}+ \\
& \delta_{2} L V A_{t-i}+\delta_{3} L V I_{t-i}+ \\
& \delta_{4} L V S_{t-i}+\delta_{5} L H E_{t-i}+ \\
& \delta_{6} L H E_{t-i}+\varepsilon_{t}
\end{aligned}
$$

Dimana $\Delta$ adalah simbol bentuk perbedaan pertama; $\beta_{i} \quad(i=1,2,3,4,5,6) \quad$ adalah parameter hubungan jangka pendek yang diperkirakan; $\delta_{i}(i=1,2,3,4,5,6)$ adalah parameter hubungan jangka panjang yang diperkirakan; $t$ adalah periode waktu; $k, l$, $m, n, o, p$ adalah optimal lag yang ditentukan menggunakan Akaike's Information Criterion (AIC) yang diperkenalkan oleh (Akaike, 1974); t adalah periode waktu dan $\varepsilon$ adalah istilah kesalahan yang independen dan terdistribusi secara identik dengan rata-rata 0 dan varian.
Pengujian kointegrasi dengan prosedur uji terikat ARDL berbasis uji signifikasi gabungan F-statistik ataustatistik Wald, dengan hipotesis null $\left(H_{0}: \delta_{1}=\delta_{2}=\delta_{3}=\right.$ $\delta_{4}=\delta_{5}=\delta_{6}=0$ ) yang mengindikasikan tidak adanya kointegrasi antar variabel dan hipotesis alternative $\left(H_{1}: \delta_{1} \neq \delta_{2} \neq \delta_{3} \neq\right.$ $\delta_{4} \neq \delta_{5} \neq \delta_{6} \neq 0$ ) yang mengindikasikan adanya hubungan kointegrasi antar variabel. Pada prosedur ini, batas nilai kritis atas dan bawah untuk pengujian Fstatistik berdasarkan Narayan (2005) yang dianggap lebih sesuai untuk jumlah sampel sedikit atau terbatas. Narayan (2005) memberikan nilai kritis untuk kurang dari 80 pengamatan dengan ukuran sampel, tingkat signifikansi dan jumlah variabel yang berbeda yang terdiri dari batas nilai kritis bawah dan batas nilai kritis atas. Adanya hubungan kointegrasi disimpulkan jika nilai F-statistik lebih besar dari nilai kritis atas, sementara tidak adanya hubungan kointegrasi disimpulkan jika nilai F-statistik lebih rendah dari nilai kritis bawah. Untuk hasil dimana nilai Fstatistik berada diantara nilai kritis atas dan bawah, hubungan kointegrasi dianggap tidak meyakinkan.

Pada langkah terakhir, kita kemudian mengestimasi hubungan jangka pendek dan jangka panjang antara variabelvariabel independen dan variabel dependen. Berdasarkan persamaan 2, estimasi hubungan jangka pendek atau biasa dikenal sebagai permodelan koreksi kesalahan dapat ditulis sebagai berikut:

$$
\begin{aligned}
& \Delta L F E_{t}=\beta_{1}+\sum_{i=1}^{k} \beta_{1} L F E_{t-i}+ \\
& \sum_{i=0}^{l} \beta_{2} \Delta L V A_{t-i}+ \\
& \sum_{i=0}^{m} \beta_{3} \Delta L V I_{t-i}+ \\
& \sum_{i=0}^{n} \beta_{4} \Delta L V S_{t-i}+ \\
& \sum_{i=0}^{o} \beta_{5} \Delta L H E_{t-i}+ \\
& \sum_{i=0}^{p} \beta_{6} \Delta L T R_{t-i}+\pi E C T_{t-i}+\varepsilon_{t}
\end{aligned}
$$


Dimana $\pi$ adalah koefisien jangka panjang dan ECT atau error correction term adalah representasi model jangka panjang yang mencerminkan keseimbangan hubungan jangka panjang pada model. Adanya kesimbangan jangka panjang pada model koreksi kesalahan disimpulkan apabila koefisien dari ECT $(\pi)$ bernilai negatif dan sekurangnya signifikan secara statistic pada tingkat $5 \%$, dimana besaran nilai koefisien dari istilah koreksi kesalahan tersebut menunjukan seberapa cepat data seri mencapai keseimbangan hubungan jangka panjang. Adapun persamaan hubungan jangka panjang yang diproyeksi oleh ECT dapat ditulis sebagai berikut:

$E C T_{t-1}=L F E_{t-1}-a_{0}-$

$a_{1} L V A_{1 t}-a_{2} L V I_{2 t}-a_{3} L V S_{3 t}-$

$a_{3} L H E_{3 t}-a_{3} L T R_{3 t}$

Pada model koreksi kesalahan (persamaan 3), kami menerapkan uji-uji diagnostic pada model seperti uji statistik Jarquebera untuk normalitas, uji lagrangemultiplier untuk serial korelasi, uji Breusch-Pagan-Godfrey untuk heteroskedastisitas dan uji Ramsey Regression Equation Specification Error Test (RESET) untuk bentuk fungsi spesifikasi model. Selain itu, kami juga memeriksa stabilitas koefisien-koefisien seluruh variabel pada model estimasi menggunakan grafik cumulative sum (CUSUM) dan cumulative sum of squares (CUSUMQ) yang diperkenalkan oleh (Brown et al, 1975).

\section{Hasil Analisis dan Diskusi}

Tabel 3 melaporkan hasil uji stationaritas atau uji unit root untuk seluruh data series yang digunakan dalam penelitian ini. Dapat dilihat bahwa ketika seluruh data seri diuji hanya dengan intersep, hasil ujistationaritas $\mathrm{ADF}$ dan $\mathrm{PP}$ menunjukan bahwa data seri dari LVA, LVS, LHE, dan LFE memiliki stationaritas pada tingkat I(0) maupun I (1), sementara data seri dari LVI dan LTR hanya stasioner pada tingkat I(1). Selanjutnya, hasil uji stationaritas ADF dan PP dengan intersep dan trend menunjukan bahwa seluruh data seri tidak stationer pada bentuk I (0) dan hanya stasioner ketika ditransformasi ke dalam bentuk perbedaan pertama atau $\mathrm{I}(1)$. Berdasarkan hasil ini dapat disimpulkan bahwa seluruh data seri yang akan digunakan dalam penelitian ini memenuhi syarat untuk dianalisis menggunakan prosedur ARDL, dimana prosedur ini hanya mensyaratkan seluruh data seri yang digunakan dalam penelitian ini memiliki stasionaritas pada tingkat I (0) dan/atau I (1).

Table 3. Hasil uji stasionaritas dari tes ADF and PP.

\begin{tabular}{ccccc}
\hline \multirow{2}{*}{ Data Seri } & \multicolumn{2}{c}{ Pengujian hanya dengan intersep } & \multicolumn{2}{c}{ Pengujian hanya dengan intersep dan tren } \\
\cline { 2 - 5 } & ADF & PP & ADF & PP \\
\hline LVA & -0.226 & -0.226 & -1.502 & -1.647 \\
LVI & $-3.024^{* *}$ & $-3.024^{* *}$ & -2.259 & -2.259 \\
LVS & -1.541 & -1.303 & -2.410 & -2.219 \\
LHE & -2.202 & -2.051 & -1.863 & -1.909
\end{tabular}




\begin{tabular}{ccccc} 
LTR & $-3.193 * *$ & $-3.162 * *$ & -2.858 & -2.788 \\
LFE & -2.484 & -2.482 & -0.118 & -0.078 \\
\hline$\Delta$ LVA & $-6.333 * * *$ & $-6.334 * * *$ & $-6.257 * * *$ & $-6.258 * * *$ \\
$\Delta$ LVI & $-4.857 * * *$ & $-4.860 * * *$ & $-5.249 * * *$ & $-5.264 * * *$ \\
$\Delta$ LVS & $-4.435 * * *$ & $-4.433 * * *$ & $-4.473 * * *$ & $-4.479 * * *$ \\
$\Delta$ LHE & $-4.865 * * *$ & $-4.861 * * *$ & $-5.298 * * *$ & $-5.315 * * *$ \\
$\Delta$ LTR & $-8.742 * * *$ & $-9.128 * * *$ & $-9.005 * * *$ & $-10.007 * * *$ \\
$\Delta$ LFE & $-5.564 * * *$ & $-5.583 * * *$ & $-6.409 * * *$ & $-6.409 * * *$
\end{tabular}

Keterangan : $\Delta$ adalah simbol bentuk perbedaan pertama. $* * *, * *, *$ berturut-turut menunjukan bahwa data seri stasioner dengan tingkat signifikan $1 \%, 5 \%$ and $10 \%$.

Tabel 4 melaporkan hasil uji kointegrasi terhadap model persamaan yang dianalisis dalam penelitian ini. Pemilihan jumlah lag optimal untuk masing-masing variable dalam model persamaan ditentukan menggunakan kriteria Akaike Information Criterion (AIC), dimana kemudian kriteria ini menentukan panjang lag optimal yang sesuai untuk data seri LFE, LVA, LVI, LVS, LHE, dan LTR dalam model persamaan berturut-turut adalah 2, 2, 1, 2, 2, 1. Selanjutnya hasil uji terikat menunjukan bahwa nilai F-statistic berada di atas nilai batas kritis atas dari nilai kritis yang Tabel 4. Hasil pengujian kointegrasi diusulkan oleh Narayan (2005) dengan tingkat signifikansi $1 \%$. Hasil ini menunjukan bahwa terdapat hubungan kointegrasi atau keseimbangan jangka panjang yang berjalan dari variabel-variabel independent ke variabel dependen dalam model estimasi. Dengan kata lain, pertumbuhan ekonomi toga sektor utama pembangunan, pengeluaran konsumsi final rumah tangga, dan keterbukaan perdagangan memiliki hubungan kointegrasi terhadap konsumsi energi final di Indonesia.

\begin{tabular}{|c|c|c|c|}
\hline Model & & ptimal & F-statistik \\
\hline LFE $\|$ LVA LVI LVS LHE LTR & & $2,2,1$ & $6.365 * * *$ \\
\hline \multirow{2}{*}{ Nilai Kritis } & \multicolumn{3}{|c|}{ Tingkat Signifikasi } \\
\hline & $1 \%$ & $5 \%$ & $10 \%$ \\
\hline Batas Bawah, I(0) & 4.030 & 2.922 & 2.458 \\
\hline Batas Atas, I(1) & 5.598 & 4.268 & 3.647 \\
\hline
\end{tabular}

Keterangan : ***, **, *berturut-turut menunjukan signifikansi pada tingkat 1\%, 5\% dan 10\%. Nilai batas kritis atas dan bawah berdasarkan Narayan (2001) untuk $n=45$ dan $k=5$. 
Tabel 5 melaporkan koefisien jangka panjang dari masing-masing independen variabel terhadap variabel dependen. Dapat dilihat bahwa koefisien LVA, LVI, dan LTR bernilai positif dan significant pada tingkat $1 \%$. Hasil ini menunjukan bahwa peningkatan pertumbuhan nilai tambah pada sektor pertanian dan sektor industri dalam jangka panjang berpotensi mendorong semakin meningkatnya jumlah konsumsi energi akhir di Indonesia, begitupun sebaliknya. Selanjutnya, koefisien LVS dan LHE bernilai negatif dan secara statistik signifikan pada tingkat
1\%. Hasil ini menunjukan bahwa pertumbuhan nilai tambah pada sektor pelayanan dan pengeluaran akhir rumah tangga dalam jangka panjang berpotensi mengurangi pertumbuhan konsumsi energi akhir di Indonesia, begitupun sebaliknya. Berdasarkan hasil ini maka dapat disimpulkan bahwa pertumbuhan ekonomi pada tiga sektor utama pembangunan, pengeluaran konsumsi akhir rumah tangga dan keterbukaan perdagangan memiliki pengaruh terhadap konsumsi energi di Indonesia dalam periode jangka panjang.

Table 5. Koefisien hubungan Jangka Panjang (DV: LFEC).

\begin{tabular}{ccccc}
\hline Variabel & Koefisien & Standar Error & t-value & Prob \\
\hline C & $-3.678^{* * *}$ & 0.833 & -4.416 & 0.000 \\
LVA & $1.151^{* * *}$ & 0.167 & 6.892 & 0.000 \\
LVI & $0.966^{* * *}$ & 0.103 & 9.405 & 0.000 \\
LVS & $-0.543^{* * *}$ & 0.114 & -4.757 & 0.000 \\
LHE & $-0.316^{* * *}$ & 0.108 & -2.931 & 0.007 \\
LTR & $0.250^{* * *}$ & 0.048 & 5.162 & 0.000 \\
\hline
\end{tabular}

Keterangan : ***,**, * berturut-turut menunjukan signifikansi pada tingkat $1 \%, 5 \%$ and $10 \%$.

Tabel 4 melaporkan koefisien jangka pendek dan istilah koreksi kesalahan. Koefisien LVA bernilai negatif dan tidak signifikan, sementara koefisien $\triangle \mathrm{LVA}(-1)$ bernilai negatif dan signifikan pada tingkat 1\%. Bukti ini menunjukan bahwa pertumbuhan nilai tambah sektor pertanian pada akhir periode jangka pendek berpotensi mengurangi konsumsi energi final di Indonesia. Koefisien LVI bernilai positif dan signifikan pada tingkat 5\%. Hasil ini menunjukan bahwa pertumbuhan nilai tambah pada sektor Industri berpotensi mendorong semakin meningkatnya jumlah konsumsi energi final di Indonesia. Koefisien LVS dan LVS(-1) bernilai positif namun secara statistik tidak signifikan. Hasil ini menggambarkan bahwa pertumbuhan nilai tambah pada sektor pelayanan tidak memberikan pengaruh terhadap pertumbuhan konsumsi energi akhir di Indonesia. 
Tabel 6. Koefisien hubungan jangka pendek dan istilah koreksi kesalahan (DV: LFEC).

\begin{tabular}{|c|c|c|c|c|}
\hline Variabel & Koefisien & $\begin{array}{l}\text { Standar } \\
\text { Error }\end{array}$ & t-value & Prob \\
\hline $\mathrm{C}$ & $-3.853 * * *$ & 0.579 & -6.659 & 0.000 \\
\hline$\Delta(\operatorname{LFEC}(-1))$ & $0.332 * *$ & 0.137 & 2.427 & 0.022 \\
\hline$\Delta(\mathrm{LVA})$ & -0.070 & 0.247 & -0.282 & 0.780 \\
\hline$\Delta \operatorname{LVA}(-1)$ & $-0.704 * * *$ & 0.246 & -2.859 & 0.008 \\
\hline$\Delta \mathrm{LVI}$ & $0.418 * *$ & 0.157 & 2.656 & 0.013 \\
\hline$\Delta \mathrm{LVS}$ & 0.143 & 0.165 & 0.870 & 0.392 \\
\hline$\Delta \operatorname{LVS}(-1)$ & 0.198 & 0.117 & 1.684 & 0.104 \\
\hline$\Delta \mathrm{LHE}$ & -0.050 & 0.144 & -0.345 & 0.732 \\
\hline$\Delta \mathrm{LHE}(-1)$ & $-0.302 * *$ & 0.119 & -2.542 & 0.017 \\
\hline$\Delta \mathrm{LTR}$ & $0.111^{* * *}$ & 0.035 & 3.195 & 0.004 \\
\hline ECT(-1) & $-1.048^{* * *}$ & 0.156 & -6.728 & 0.000 \\
\hline R-squared & \multicolumn{2}{|c|}{0.703} & & \\
\hline Adj. R-squared & \multicolumn{2}{|c|}{0.610} & & \\
\hline DW statistik & \multicolumn{2}{|c|}{2.294} & & \\
\hline Jarque-Bera & \multicolumn{2}{|c|}{$2.945(0.229)$} & & \\
\hline LM & \multicolumn{2}{|c|}{$2.856(0.076)$} & & \\
\hline BPG & \multicolumn{2}{|c|}{$1.029(0.458)$} & & \\
\hline RESET & \multicolumn{2}{|c|}{$0.546(0.467)$} & & \\
\hline
\end{tabular}

Note : $\Delta$ adalah simbol bentuk perbedaan pertama. $* * *, * *, *$ berturut-turut menunjukan signifikansi pada tingkat $1 \%, 5 \%$ and $10 \%$.

Koefisien LHE bernilai negatif dan secara statistik signifikan pada tingkat $1 \%$, sebaliknya meski koefisien LHE (-1) juga bernilai negatif namun secara statistic tidak signifikan. Bukti ini menunjukan bahwa peningkatan pengeluaran akhir rumah tangga pada awal periode jangka pendek berpotensi mengurangi konsumsi energi final di Indonesia namun pada akhir jangka pendek peningkatan pengeluaran akhir rumah tangga tidak memiliki dampak signifikan terhadap laju pertumbuhan konsumsi energi akhir di Indonesia. Koefisien LTR bernilai positif dan signifikan pada tingkat 5\%. Hasil ini menunjukan bahwa keterbukaan perdagangan memiliki dampak positif dan mendorong peningkatan jumlah konsumsi energi akhir di Indonesia dalam periode jangka pendek. Selanjutnya koefisien
ECT(-1) memiliki nilai negatif dan secara statistic signifikan pada tingkat $1 \%$. Hasil ini menunjukan bahwa ada keseimbangan jangka panjang dalam model, dimana perubahan yang terjadi pada periode jangka pendek akan sangat cepat mempengaruhi hubungan antara variabelvariabel independen dan variabel dependen dalam periode jangka panjang.

Selanjutnya, nilai R-squared dan adjustment R-squared berturut-turut adalah 0.70 dan 0.61 yang menujukan bahwa indikator yang digunakan sebagai variabelvariabel independen pada model secara statistic hanya dapat memperkirakan sekitar $61 \%$ hingga $70 \%$ perubahan variabel dependen, sementara sisanya dipengaruhi oleh indicator-indicator lainnya yang tidak dimasukan dalam model persamaan. Nilai statistik Durbin- 
Watson memiliki nilai mendekati 2 yang menunjukan bahwa tidak ada permasalahan korelasi berseri pada model estimasi. Statistic Jarque-bera, tes LM, Brush-pagan-gofrey dan Ramsey RESET berturut-turut menunjukan bahwa model estimasi bebas dari masalah normalitas, autokorelasi, heterogenitas, dan kesalahan spesifikasi model. Selanjutnya gambar 1 menunjukan plot Cumulative Sum (CUSUM) dan Cumulative Sum of squared (CUSUMSq). Dapat dilihat bahwa garis biru pada plot CUSUM dan CUSUM of squares tidak melampui garis batas nilai kritis (garis merah). Hasil ini menunjukan bahwa variabel-variabel dalam model estimasi tetap stabil sepanjang periode waktu.

Gambar 1. Grafik CUSUM dan CUSUM of Squares

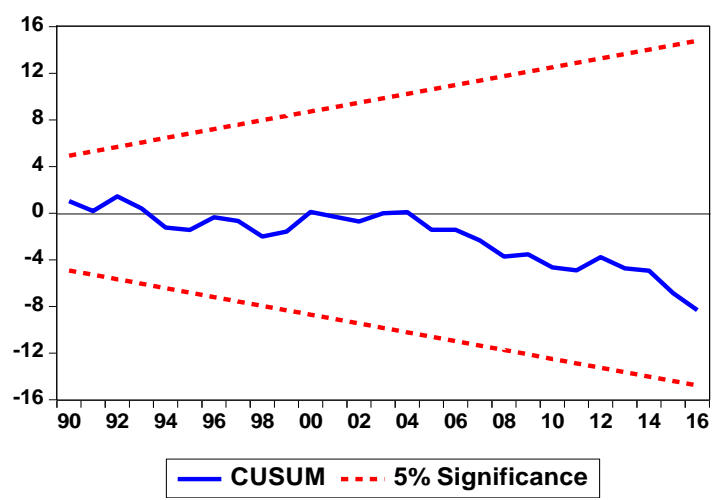

Kesimpulan dan Implikasi Kebijakan

Tujuan penelitian ini adalah mengkaji dampak pertumbuhan ekonomi pada tiga sektor utama pembangunan, pengeluaran konsumsi akhir rumah tangga, dan keterbukaan perdagangan terhadap pertumbuhan konsumsi energi akhir di Indonesia dengan menggunakan data tahunan selama periode 1972-2016 yang diperoleh dari World Development Indicator (World Bank, 2018) dan International Energi Agency (IEA, 2018). Metode analisis yang digunakan dalam penelitian ini adalah autoregressive distributed lag (ARDL), dimana langkah analisis yang dilakukan adalah uji stasioneritas seri data, uji kointegrasi, estimasi jangka panjang serta estimasi koefisien jangka pendek dan istilah koreksi kesalahan. Seluruh prosedur analisis

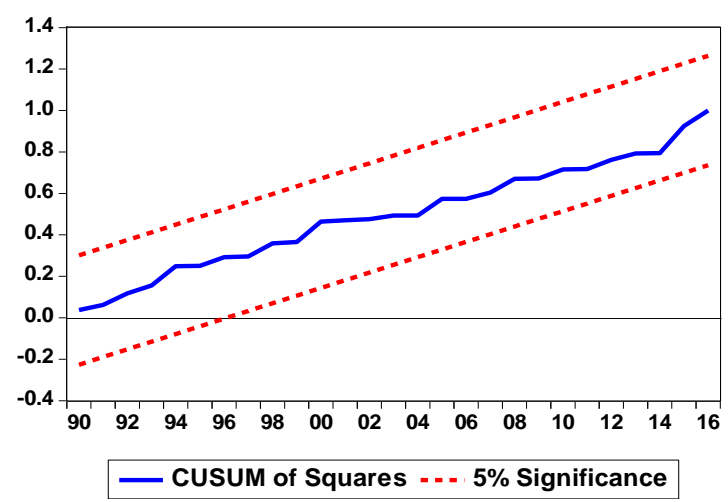

diestimasi dan diolah dengan menggunakan program statistic Eviews versi 9.5.

Hasil analisis mengungkapkan beberapa temuan empiris yang diharapkan menjadi perhatian bagi para pemangku kebijakan di Indonesia. Pertama, pertumbuhan nilai tambah sektor industri dan keterbukaan perdagangan berpotensi mendorong peningkatan konsumsi energi akhir di Indonesia dalam jangka pendek dan jangka panjang. Kedua, Pertumbuhan ekonomi pada sektor pertanian dalam jangka pendek berpotensi mengurangi konsumsi energi akhir di Indonesia, namun sebaliknya dalam jangka panjang dapat menyebabkan peningkatan konsumsi energi akhir di Indonesia. Ketiga, pertumbuhan pengeluaran konsumsi akhir rumah tangga berpotensi menyebabkan konsumsi energi akhir di Indonesia menurun dalam jangka pendek dan jangka panjang. Keempat, pertumbuhan 
ekonomi sektor pelayanan berpotensi menurunkan konsumsi energi akhir Indonesia hanya pada dalam jangka pendek.

Berdasarkan hasil ini maka disimpulkan bahwa pembangunan ekonomi berkelanjutan di Indonesia sangat perlu diiringi dengan kebijakan dan strategi berkaitan penyediaan sumber energi yang mencukupi kebutuhan domestik. Pemerintah Indonesia diharapkan dapat menentukan kebijakan dan strategi yang tepat dalam rangka menghadapi tantangan isu berkaitan keamanan energi di masa depan yang bukan saja dalam hal peningkatan kuantitas pasokan energi namun juga berkaitan dengan semakin meningkatnya harga energi konvensional pada masa depan. Percepatan pengembangan sumber energi baru dan terbarukan dianggap menjadi salah satu solusi dalam menghadapi kelangkaan dan peningkatan harga sumber energi yang berasal fosil di masa depan. Selain itu, dibutuhkan juga peran serta seluruh pengguna energi akhir di Indonesia untuk lebih efisien dalam mengkonsumsi energi akhir dalam kegiatan mereka masingmasing.

\section{Daftar Pustaka}

Afzal, M., Ehsan, M., Butt, M. A. R., \& Fatima, K. (2013). Openness, inflation, and growth relationship in Pakistan: An application of ARDL bounds testing approach. Pakistan Economic and Social Review, 51(1), 13-53. Retrieved from http://pu.edu.pk/images/journal/pesr/PDFFILES/2 AFZAL Openness Inflation and Growth Relationships in Pak_v51_no1_2013.pdf

Akaike, H. (1974). A New Look at the Statistical Model Identification. IEEE Transactions on Automatic Control, 19(6), 716-723.
https://doi.org/10.1109/TAC.1974.1100705

Al-mulali, U. (2012). Factors affecting CO2 emission in the Middle East: A panel data analysis. Energy, 44(1), 564-569. https://doi.org/10.1016/j.energy.2012.05.045

Alam, M. M., Murad, M. W., Noman, A. H. M., \& Ozturk, I. (2016). Relationships among carbon emissions, economic growth, energy consumption and population growth: Testing Environmental Kuznets Curve hypothesis for Brazil, China, India and Indonesia. Ecological Indicators, 70, 466-479. https://doi.org/10.1016/j.ecolind.2016.06.043

Apergis, N., \& Tang, C. F. (2013). Is the energyled growth hypothesis valid? New evidence from a sample of 85 countries. Energy Economics, $\quad 38, \quad 24-31$. https://doi.org/10.1016/j.eneco.2013.02.007

Aramcharoen, A., \& Mativenga, P. T. (2014). Critical factors in energy demand modelling for $\mathrm{CNC}$ milling and impact of toolpath strategy. Journal of Cleaner Production, 78, 63-74.

https://doi.org/10.1016/j.jclepro.2014.04.065

Aydin, E., \& Brounen, D. (2019). The impact of policy on residential energy consumption. Energy, 169, 115-129. https://doi.org/10.1016/j.energy.2018.12.030

Azam, M., Khan, A. Q., Bakhtyar, B., \& Emirullah, C. (2015a). The causal relationship between energy consumption and economic growth in the ASEAN-5 countries. Renewable and Sustainable Energy Reviews, 47, 732-745. https://doi.org/10.1016/j.rser.2015.03.023

Azam, M., Khan, A. Q., Zaman, K., \& Ahmad, M. (2015b). Factors determining energy consumption: Evidence from Indonesia, Malaysia and Thailand. Renewable and Sustainable Energy Reviews, 42, 1123-1131. https://doi.org/10.1016/j.rser.2014.10.061

Bank Indonesia. (2018). Laporan Perekonomian Indonesia 2018. Retrieved from https://www.bi.go.id/id/publikasi/laporan- 
tahunan/perekonomian/Pages/LPI_2018.aspx

Bhattacharyya, S. C. (2011). Energy Economics: Concepts, Issues, Markets and Governance. Springer-Verlag London Limited 2011. https://doi.org/10.1007/978-0-85729-268-1

Brown, R. L., Durbin, J., \& Evans, J. M. (1975). Techniques for Testing the Constancy of Regression Relationships Over Time. Journal of the Royal Statistical Society: Series B (Methodological), 37(2), 149-192. https://doi.org/10.1111/j.25176161.1975.tb01532.x

Chiou-Wei, S. Z., Chen, C. F., \& Zhu, Z. (2008). Economic growth and energy consumption revisited - Evidence from linear and nonlinear Granger causality. Energy Economics, 30(6), 3063-3076. https://doi.org/10.1016/j.eneco.2008.02.002

Dickey, D. A., \& Fuller, W. A. (1979). Distribution of the Estimators for Autoregressive Time Series With A Unit Root. Journal of the American Statistical Association, 74(336), 427-431.

Dutu, R. (2016). Challenges and policies in Indonesia's energy sector. Energy Policy, 98, 513-519. https://doi.org/10.1016/j.enpol.2016.09.009

Hwang, J. H., \& Yoo, S. H. (2014). Energy consumption, $\mathrm{CO} 2$ emissions, and economic growth: Evidence from Indonesia. Quality and Quantity, 48(1), 63-73. https://doi.org/10.1007/s11135-012-9749-5

International Energy Agency/IEA. (2019). IEA online data services. Retrieved fromhttp://wds.iea.org/wds/ReportFolders /ReportFolders.aspx?CS_referer $=\& C S \_C$ hosenLang=en

Javid, M., \& Sharif, F. (2016). Environmental Kuznets curve and fi nancial development in Pakistan. Renewable and Sustainable Energy Reviews, 54, 406-414. https://doi.org/10.1016/j.rser.2015.10.019

Mah, J. S. (2000). An empirical examination of the disaggregated import demand of Korea - The case of information technology products. Journal of Asian Economics, 11, 237-244. https://doi.org/10.1016/S10490078(00)00053-1

Mahadevan, R., \& Asafu-Adjaye, J. (2007). Energy consumption, economic growth and prices: A reassessment using panel VECM for developed and developing countries. Energy Policy, 35(4), 2481-2490. https://doi.org/10.1016/j.enpol.2006.08.019

Narayan, P. K. (2005). The saving and investment nexus for China: Evidence from cointegration tests. Applied Economics, 37(17), 1979-1990. https://doi.org/10.1080/00036840500278103

Nugraha, A.T., \& Osman, N. H. (2018). The environmental study on causality relationship among energy consumption, $\mathrm{CO} 2$ emissions, the value added of development sectors and household final consumption expenditure in Indonesia. Ekoloji, 27(106).

Nugraha, A.T., \& Osman, N. H. (2019). CO2 emissions, economic growth, energy consumption, and household expenditure for Indonesia: Evidence from cointegration and vector error correction model. International Journal of Energy Economics and Policy, 9(1). https://doi.org/10.32479/ijeep.7295

Nugraha, A. T., \& Osman, N. H. (2017). The energy-economic growth nexus in Indonesia. Journal of Business Management and Accounting, 7(2), 61-75.

Ozturk, I. (2010). A literature survey on energygrowth nexus. Energy Policy, 38(1), 340349. https://doi.org/10.1016/j.enpol.2009.09.024

Perron, P., \& Phillips, P. C. B. (1988). Testing for a Unit Root in a Time Series Regression. Biometrika, 2(75), 335-346. https://doi.org/10.1080/07350015.1992.1050 9923

Pesaran, M. H., \& Shin, Y. (1998). An Autoregressive Distributed-Lag Modelling 
Approach to Cointegration Analysis. Econometric Society Monographs, 31, 371413. https://doi.org/10.1017/ccol0521633230.011

Pesaran, M. Hashem, Shin, Y., \& Smith, R. J. (2001). Autoregressive Distributed Lag (ARDL) cointegration technique : application and interpretation. Journal of Statistical and Econometric Methods, 5(3), 63-91. https://doi.org/10.1002/jae.616

Saboori, B., \& Sulaiman, J. (2013). CO2 emissions, energy consumption and economic growth in association of Southeast Asian Nations (ASEAN) countries: Acointegration approach. Energy, 55, 813822.

https://doi.org/10.1016/j.energy.2013.04.038

Saez-Martinez, F. J., Modejar-Jimenez, J., \& Modejar-Jimenez, J. A. (2015). The energy challenge: energy and Environment Knowledge Week E2KW 2013. Journal of Cleaner Production, 86, 471-473. https://doi.org/10.1016/j.jclepro.2014.08.044

Shahbaz, M., Hye, Q. M. A., Tiwari, A. K., \& Leitão, N. C. (2013a). Economic growth, energy consumption, financial development, international trade and $\mathrm{CO} 2$ emissions in Indonesia. Renewable and Sustainable Energy Reviews, 25, 109-121. https://doi.org/10.1016/j.rser.2013.04.009

Shahbaz, M., Khan, S., \& Tahir, M. I. (2013b). The dynamic links between energy consumption, economic growth, financial development and trade in China: Fresh evidence from multivariate framework analysis. Energy Economics, $\quad 40, \quad 8-21$. https://doi.org/10.1016/j.eneco.2013.06.006

Shahbaz, M., Loganathan, N., Sbia, R., \& Afza, T. (2015). The effect of urbanization, affluence and trade openness on energy consumption: A time series analysis in Malaysia. Renewable and Sustainable Energy Reviews, 47 , 683-693. https://doi.org/10.1016/j.rser.2015.03.044

Sulaiman, J., Azman, A., \& Saboori, B. (2013).
The potential of renewable energy: Using the environmental kuznets curve model. American Journal of Environmental Sciences, $\quad 9(2), \quad 103-112$. https://doi.org/10.3844/ajessp.2013.103.112

Tiba, S., \& Frikha, M. (2018). Income, trade openness and energy interactions: Evidence from simultaneous equation modeling. Energy, $\quad 147, \quad 799-811$. https://doi.org/10.1016/j.energy.2018.01.013

Van Raaij, F. W., \& Verhallen, T. M. M. (1983). a Behavioral Model of Residential Energy Use. Journal of Economic Psychology, 3, 39-63.

Verhallen, T. M. M., \& Van Raaij, W. F. (1981). Household Behavior and the Use of Natural Gas for Home Heating. Journal of Consumer Research, 8(3), 253-257. https://doi.org/10.1086/208862

Wahid, I. N., Azlina, A. A., \& Mustapa, N. H. N. (2013). Energy consumption, economic growth and $\mathrm{CO} 2$ emissions in selected ASEAN countries. Prosiding Perkembangan Kebangsaan Ekonomi Malaysia Ke VIII 2013, 2, 758-765.

World Bank. (2018). World Development Indicators (online database). Retrieved from https://datacatalog.worldbank.org/dataset/wor ld-development-indicators

Yildirim, E., Sukruoglu, D., \& Aslan, A. (2014). Energy consumption and economic growth in the next 11 countries: The bootstrapped autoregressive metric causality approach. Energy Economics, 44, 14-21. https://doi.org/10.1016/j.eneco.2014.03.010

Zachariadis, T. (2007). Exploring the relationship between energy use and economic growth with bivariate models: New evidence from G-7 countries. Energy Economics, 29(6), 1233-1253. https://doi.org/10.1016/j.eneco.2007.05.001 